\title{
Exploring Factors Influencing Resilience Among Flood Victims in Malaysia
}

Noremy Md. Akhir, Nur Saadah Mohamad Aun, Mohd Nasir Selamat \& Aizan Sofia Amin

To Link this Article: http://dx.doi.org/10.6007/IJARBSS/v11-i6/10227

DOI:10.6007/IJARBSS/v11-i6/10227

Received: 10 April 2021, Revised: 13 May 2021, Accepted: 29 May 2021

Published Online: 18 June 2021

In-Text Citation: (Akhir et al., 2021)

To Cite this Article: Akhir, N. M., Aun, N. S. M., Selamat, M. N., \& Amin, A. S. (2021). Exploring Factors Influencing Resilience Among Flood Victims in Malaysia. International Journal of Academic Research in Business and Social Sciences, 11(6), 969-981.

\section{Copyright: (c) 2021 The Author(s)}

Published by Human Resource Management Academic Research Society (www.hrmars.com)

This article is published under the Creative Commons Attribution (CC BY 4.0) license. Anyone may reproduce, distribute, translate and create derivative works of this article (for both commercial and non-commercial purposes), subject to full attribution to the original publication and authors. The full terms of this license may be seen at: http://creativecommons.org/licences/by/4.0/legalcode

Vol. 11, No. 6, 2021, Pg. 969- 981

Full Terms \& Conditions of access and use can be found at http://hrmars.com/index.php/pages/detail/publication-ethics 


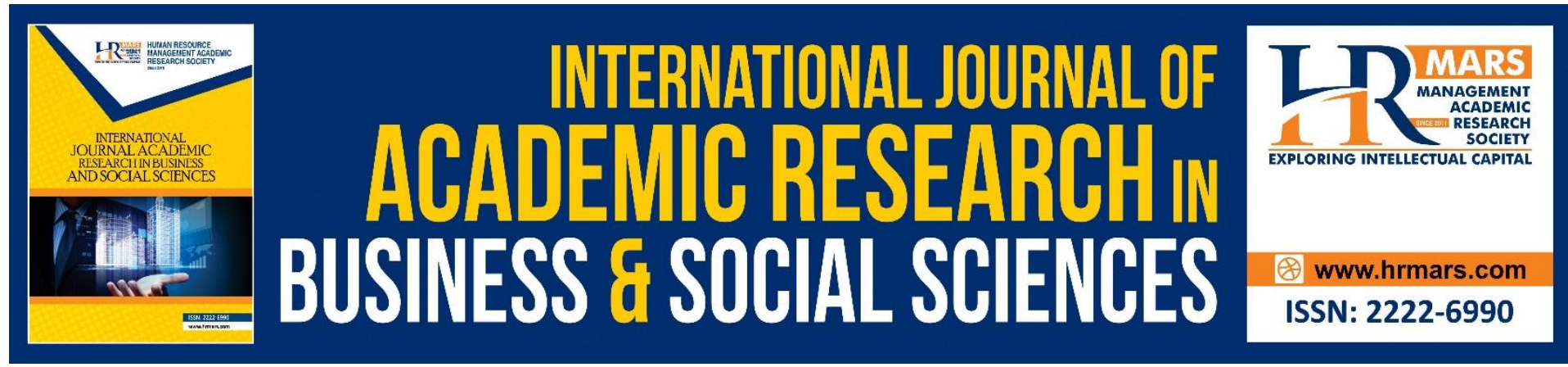

\title{
Exploring Factors Influencing Resilience Among Flood Victims in Malaysia
}

\author{
Noremy Md. Akhir, Nur Saadah Mohamad Aun, Mohd Nasir \\ Selamat \& Aizan Sofia Amin \\ Centre for Psychology and Human Well-being Research, Faculty of Social Sciences and \\ Humanities, Universiti Kebangsaan Malaysia Selangor, Malaysia \\ Email: noremy@ukm.edu.my
}

\begin{abstract}
In December 2014, Malaysia was shocked by the massive floods that affect physical destruction and also leaving flood victims with psychological problems. Based on previous research, resiliency is an element that can protect the flood victims from experiencing severe psychological issues. Therefore, the objective of this study was to explore the factors influencing resiliency among flood victims in Kelantan, Malaysia. To carry out this study, a qualitative approach using case study as a research design was employed. A total of 28 flood victims were selected for in-depth interview sessions. Respondents were selected by using purposive sampling. The data were collected and analysed using thematic analysis. The findings reported that there were four factors that influenced respondents' resiliency, which emerged as themes namely self-efficiency, coping strategies, characteristics of community spirit and social support. The finding would provide information for relevant intervention programme which will lead to improve the physical and psychological well-being of flood victims in Malaysia.
\end{abstract}

Keywords: Resilience, Psychological Issues, Disaster, Flood Victims, Malaysia

\section{Introduction}

Malaysia is located outside the Pacific Ring of Fire and is thus not affected by devastations and damages caused by natural disasters such as volcanoes, earthquakes, or hurricanes. However, the Malaysian Meteorological Department reports floods occurring almost every year in the country due to heavy rains that fall between November and March (Wan Hassan, Subramaniam \& Yap, 2012). According to Wan Nik (2015), Kelantan State which was located at the east coast of Malaysia experiences flood almost every year because of climatic factors, such as the shift in the Northeast of Monsoon and due to the natural landforms of Kelantan. Nonetheless, the December 2014 flood in Kelantan was unprecedented and was declared as the largest and worst flood event in the state.

Based on online-flooding records of Kelantan State, non-stop heavy rainfall on Mount Gagau (Gua Gagau) recorded the highest rainfall over three consecutive days from December 21 to December 23, 2014, amounting to $1295 \mathrm{~mm}$. The amount of rainfall in those three days 
equalled the amount of rainfall throughout 64 days, $400 \mathrm{~mm}$ equivalent to 20 raining days. This situation caused Kelantan to experience severe and massive floods (Department of Drainage and Irrigation Kelantan, 2015). The December 2014 flood disaster affected almost all districts in Kelantan, with more than 120,000 flood victims were sheltered at relief centres. It was also reported that 11 people were killed and 2,374 houses were completely damaged or destroyed (total loss), on top of severe damages to government assets and infrastructures. As a result, the government had to suffer damages and losses estimated at more than Ringgit Malaysia (RM) 1 billion (Economic Planning Unit of Kelantan State, 2015). Besides losing physical properties, the flood victims also faced psychological issues due to the disaster (Norizan, 2016; Noremy, Nur Saadah \& Nor Jana, 2019a). The Department of Social Welfare discovered that 14,995 children and 289 adults were diagnosed with depression and trauma after going through the catastrophic flood event (Rohani, 2015). Most of the post-traumatic flood victims experienced mental shock because of the total loss of their properties (Sikh, 2015). The psychological effects have caused emotional strain or tension to flood victims, which in turn, caused them to be mentally and emotionally helpless, as well as physically affected or impaired (Noremy et al., 2019b).

\section{Literature Review}

Based on prior studies, resilient elements that could reduce psychological problems from affecting people have been identified (Maruzairi, Mohd Zawari \& Wan Nor Arifin, 2015; Rosnah et al., 2015). Resilience is the ability of individuals to adapt and recover from critical situations or disasters, which have disrupted their life (Pfefferbaum, 2013). In this study, resilience is defined as the ability and capability of flood victims to rise and recover to restore their social functioning, which has been affected due to flood disasters. Based on community resilience model, Paton (2005) defines community resilience as the ability of people to adapt, survive and recover from disruption and loss during disaster. This model recommend that there are three levels: personal, community and institutional level. At the personal level, people need to know that the small things they do can make a positive difference for themselves, their families and people around them. At this level, people's problem-solving skills (action coping) are developed, their belief in the benefits of flood disasters mitigation and their ability to confront flood disasters are mitigated.

Meanwhile, the second level is that of community where active involvement in community affairs is encouraged and the community's ability to resolve collective issues is developed. The third level is the institutional level where communities are supported by civic agencies that encourage and empower community-lead initiative and where mutual trust and respect exist. In fact, support provided is seen as a process of facilitating resilience within individual, families and communities that have lived through disasters. It is thus seen that natural disaster victims who possess resilience are able to reduce psychological problems and ensure retention of positive mental health. Hence, the objective of this study was aimed to explore the factors that influenced resilience of flood victims after a disaster event.

\section{Methodology}

This is a qualitative research that used case studies as the research design. Qualitative research tends to produce complex data with the information needed. However, the data have to be interpreted based on a theoretical understanding from the literature review performed by the researcher at the beginning of the study (Siti Uzairiah, 2017). Qualitative 
research focuses on clear and in-depth explanations and insights on the studied issue. It is not based on numerical measurement or calculation. Meanwhile, a case study design comprises systematic and in-depth information on individual behaviour (Norizan, 2016). This study involved flood victims who have suffered a total loss of property. Norizan (2016) also mentioned that the case study design comprises specific events or social situations that require the researcher to examine how the behaviour or social changes occurred. This study focused on the December 2014 flood disaster in Kelantan, which caused flood victims to face a total loss or destruction of property. Thus, the case study method was appropriate as the research design for this study. Additionally, the selection of respondents was based on purposive sampling. The researcher engaged in face-to-face interviews with flood victims who have suffered from total property loss to collect the data in this study. A total of 28 respondents were chosen using inclusion criteria. The inclusion criteria are the main requirements for an individual to be chosen as a research respondent (Zainuddin, 2012). The inclusion criteria, which were determined for purposive sampling, are as follow:

\section{Inclusion Criteria}

(i) A flood victim involved in the December 2014 flood disaster in Kelantan;

(ii) A flood victim who has suffered from a total loss of house and property;

(iii) Aged 18 years old and above;

(iv) Has no mental health problems;

(v) A Malaysian citizen.

Next, the researcher conducted two sessions of in-depth and face-to-face interviews for each respondent separately. Each session took between 60 to 90 minutes to complete. The researcher also used semi-structured questions as guidelines during the sessions. The obtained data were then analysed using thematic analysis. According to Braun and Clarke (2006), thematic analysis consists of five key processes that need to be conducted by the researchers. The researchers must first familiarise themselves with the data. Second, they must generate an initial code. Third, the theme must be identified. Fourth, the theme must be studied and finally, the generated theme must be defined and renamed.

\section{Respondents' Demographics}

This study comprised 28 flood victims who have suffered from total loss of property due to the December 2014 flood disaster in Kelantan. A total of 12 male respondents and 16 female respondents participated in this study. The majority of the respondents (26) were Malay followed by two (2) Chinese respondents. The participated respondents were between 24 and 91 years old.

\section{Results and Discussion}

The results of this study indicated that four factors influenced victims' resilience, namely selfefficacy, coping strategies applied by the respondents, the characteristics of community spirit that existed in the settlement areas and the social support provided to the respondents. Each of these is discussed further below:

\section{Self-efficacy}

Based on the study conducted, the researcher discovered that self-efficacy characteristics, as shown by the respondents, influenced their resilience. Karademas (2006) stated that self- 
efficacy is how an individual acts in certain ways to achieve his goals or to handle stressful conditions. The researcher found that the respondents presented different self-efficacy characteristics, but majority demonstrated self-efficacy characteristics such as optimism and motivation to solve encountered issues, despite living in difficulties. Respondents who had these self-efficacy characteristics were observed to have better resilience and would recover immediately after the flood disaster. The fifth respondent of this study admitted that in the beginning, he was too saddened by his loss. However, he was able to control his grief by continuing with his life. The respondent also mentioned that he adapted to the new environment quickly, and successfully coped with the sorrow and hardships due to the disaster. It can be seen that the respondent was able to control his distressful emotions and thoughts.

"At first I was sad and upset but I quickly found a way out .. it is pointless if we let ourselves to be sad for long time... At last I decided to accept what's going on and I get up from my sadness."

\section{(Respondent 5)}

The respondent believed that his efforts would enable him to continue with his life after the flood disaster. Besides, the respondent stated that if he stayed in the tent (temporary shelter) without doing anything, the act would drive him to despair. The respondent was observed to keep on working and managing his daily routine and emotions. Prior research have proven that individuals with high self-efficacy could achieve enhanced life well-being, better adaptability, and could go through a rapid recovery phase (Bisschop et al., 2004; Kuijer \& De Ridder, 2003).

Similarly, a 16th respondent who was running a school canteen admitted having suffered severe losses during a massive flood. However, he did not give up trying to run a small business to sustain his life after the flood. The respondent believed that perseverance and effort will help him to recover after disaster.

"I have lost everything in the school canteen but that does not discourage me. Life must go on ... so now I do small business to survive my life after the flood " (Respondent 16)

The respondent was optimistic when searching for ways to continue his life after flood disasters. According to Symister and Friend (2003), optimism is related to positive selfefficacy. Optimism is also associated with physical health and well-being, as well as the psychological health of individuals. Majority of respondents who participated in this study were squatters with difficult life experiences. This case shows that the survival level and high self-efficacy factor had enabled them to continue living despite their difficulties.

Nevertheless, a few of the respondents did not display good self-efficacy characteristics, they refused to believe they were able to change their fate. They also frequently questioned their ability, and constantly felt discouraged, anxious and depressed about their fate and situation. For instance, the first respondent often argued and complained about why she still did not receive any help because she was already old and living in poverty. The respondent stated that she was unable to do anything since she was one of the flood victims. She also regularly confessed that she was now living in anxiety and had fears of her future. 
"I'm old already.. life is so hard after flood.. government should help me since I am a flood victim, I can't do anything.. anymore. It's hard to live like this ..living with fear and uncertain situation."

(Respondent 1)

This is similar with the 15th respondent who admitted that he was often reminded of his home which was devastated by the flood. The respondent confessed of despair, often depressed and did not know how to resolve his problem.

"I always remember my home being devastated by the floods. I feel so bad .. it was hard to accept what was going on .. I was stressed and didn't know how to solve my problem"

(Respondent 15)

Hence, this case has caused the respondent to admit that he was suffering from some stressful or depressive symptoms, such as fear, over-thinking and trauma. These symptoms caused the respondent to suffer from mental health problems. This result is in line with prior studies that found that low self-efficacy is regularly linked to anxiety and depression issues (Faure \& Loxton, 2003; Kashdan \& Roberts, 2004). In critical situations such as flooding events, self-efficacy elements are very important to generate a resilient society. Resilient growth is encouraged over attitudes of dependency or constant despair. As explained in the Community Resilience Development Theory by Paton (2005), each individual is a resource to the community. Each individual has knowledge, skills, commitment, and self-efficacy that contributes to the collective ability to grow and in turn, increase the resilient growth in the community of flood victims.

\section{Coping Strategy}

A coping strategy is a specific action taken by disaster victims either in the form of cognitive or behavioural coping strategies. It is intended to reduce or eliminate the stressful situations resulting from the interactions between the victims and their surroundings (Chaplin, 2004). Based on the results, the majority of the respondents did not apply effective coping strategies. Thus, they failed to solve their problems and ended up having a high level of dependency, especially in getting housing and financial assistance after the flood disaster. Most respondents applied a maladaptive coping strategy; only expecting assistance without putting any effort into solving their problems. According to the twentieth respondent, he refrained from doing anything that could cause him to feel overwhelmed by his loss. For example, he did not return to his house site to clean the area but instead decided to stay at the provided temporary shelter. The respondent also admitted that he had never thought of looking for another job or place to stay because he was too upset with the situation. Hence, he decided to stay in a temporary shelter while waiting for permanent housing assistance without putting in his efforts.

"..My house is damaged because of the flood. Until now I did not go to see it ... I just stay here (temporary shelter). Honestly, I didn't think about finding a new house at other place ... I just stay here until I can get aid from the government. "

(Respondent 20)

Likewise, the twelfth respondent mentioned that he was unable to find another job because he was too depressed due to the loss of his business caused by the flood. After the tragic 
flood, he would more likely isolate himself and avoid meeting people because of his overwhelming sadness, frustration, and embarrassment.

"I lost my whole business.. everything.. It was sad that I couldn't do anything ... it really hurts me .. Currently I do not prefer looking for another job... I do not want to go out .. not even to meet anyone. "

(Respondent 12)

This coping strategy is not productive and may cause social dysfunction among the flood victims. According to Carver, Scheier, and Weintraub (1989), maladaptive behaviour hinders the ability of individuals to adapt to certain situations and prevents them from effectively dealing with life pressures. This is because this coping strategy does not assist individuals to cope with their problems in the long term. Additionally, this strategy is not productive because the individual does not do anything to reduce his problems or stress. Thus, this coping strategy correlates to a low resilience level. However, some respondents used coping strategies stemming from positive religious approaches. These strategies were seen to influence and increase the respondents' resilience to rise and recover after the flooding event. For instance, the eleventh respondent viewed the incident as a fate set by God. He decided to accept his fate and move on with his life, because he believed 'every cloud has a silver lining'.

"If I feel sad, I will pray and ask for peace from God. I believes that if we keep our relationship with God, He will surely help us and give us peace. "

(Respondent 7)

"I cannot disobey God. I'm sure there is wisdom behind what is happening .. we as servants should be blessed with goodness.. I must be strong to continue my life and must always believe in God"

(Respondent 11)

By using effective coping strategies, individuals can solve problems, handle emotional stress, and can achieve their goals and overcome the crisis (Brown, Westbrook \& Challagalla, 2005), and finally enhance their resilience. Based on the Community Resilience Development Theory (Paton, 2005), individuals are encouraged to develop effective coping strategies to improve community resilience. Thus, coping strategies are considered one of the factors influencing flood resilience to increase and recover after a disastrous event.

\section{Characteristics of Community Spirit}

The third factor that influenced the respondents' resilience to recover after the flooding event was the characteristic of community spirit that existed in the residential areas. The results of this study showed two types of settlements for the flood victims, namely the provided temporary settlements and the settlements located at the respondents' house sites. These two settlements had different community spirit characteristics. The study found that respondents living at the original house site had better resilience than respondents living in temporary settlements. The respondents living at their house sites exhibited community spirit characteristics, such as feeling contented living in their original house sites and having a high sense of belonging to their homes. This is because they have been living in the area with their families for a long time. The eighth respondent also echoed the same results in which almost everyone living around his house was his family members and relatives. 
"The five houses around this area are all my relatives ... I feel safe living together with them here. If I stay at temporary shelter provided by the government I will feel uncomfortable because I don't know anyone .. it's different here, we face the hardship together and we feel strong together."

\section{(Respondent 8)}

On the other hand, those living in the provided temporary settlements showed characteristics of isolating themselves and finding it difficult to share their feelings with other flood victims. The eighteenth respondent admitted that many flood victims showed a sense of selfcentredness and always feeling unsatisfied. This case is most likely due to the limited basic needs provided in the temporary shelters. These negative attitudes hindered the respondents from rising together and building new lives after the incident. According to the eighteenth respondent, she was not even interested in taking part in any of the activity provided for the flood victims instead, she admitted that she would rather stay in her tent in the temporary settlements.

"I stay in the tent provided .. people who living here is quite self-fish because everything is limited. there are some activities and program for flood victims here, but I am not interested to join."

(Respondent 18)

Based on the results, the respondents living at the original house sites recovered faster after the flood disaster and were able to continue with their daily routines without the help of other parties despite living in poverty. This case is because the respondents had a high sense of belonging to their settlements and had strong relationships with other people living in the area. Both served to strengthen their relationships and caused them to have better resilience than the respondents living in temporary settlements along with other people from different villages and backgrounds. According to Brown, Perkins, and Brown (2003), community spirit plays an essential role in community recovery efforts, particularly after an incident or disaster. However, the sense of belonging and dependency among them is difficult to nurture because the victims do not know each other and only stay for a short period in temporary shelters. Thus, the flood victims will be unable to improve their settlement areas and would be incapable of working with community members and local agencies to improve their condition.

Brown et al. (2003) also stated that the aspects of community spirit and psychological relationships between community members critically contribute to effectively redevelop the community after any disastrous event. It requires collective action from all community members which is considered as the main resources in the community. Nonetheless, if the members fail to share the same emotions, goals, or do not complement each other, they could experience more problems in the new settlements. This is because emotional sharing and relationships between members are the foundations of community recovery after a disaster (Perkins \& Long, 2002). According to Berkman et al. (2000), socially-oriented behaviours (participation) and a sense of belonging enhance the social well-being, psychological well-being, and emotional well-being of the community members. These behaviours also increase community resilience collectively even when they face critical situations after a disaster, and eventually help them to move on with their lives. 


\section{Social Supports}

Social support provided to the respondents was acknowledged to influence the informants' resilience to recover after the flood disaster. According to the respondents in this study, the social support provided has assisted them to be more resilient in developing their new lives after the flood incident. The social support mentioned and required by the respondents included tangible support, social relationship support, information support, and emotional support. Nonetheless, the results of this study showed that only tangible support and social relationship support were received by the respondents.

"So far, in terms of food and essentials assistance was okay and I received it from government, and some NGOs.. Besides, I also got support from my sister, she helped me while I'm getting this transit house ... the other siblings are helpful and very encouraging."

\section{(Respondent 22)}

The tangible support received by the respondents consisted of aid such as foods, goods, equipments and living necessities. The respondents also mentioned that she received abundant social relationship support in the form of affection and a sense of togetherness among family members to help her recover from the flood disaster. According to Malecki and Demaray (2003), social support is seen as a form of behavioural support from social networks to improve the functionality of the affected members due to a catastrophe. Social support may enhance individual social health, well-being and resilience (Mendelson, Catano, \& Kelloway, 2000; Peeters \& LeBlanc, 2001).

In contrast, information support and emotional support from agencies or professional bodies were very minimal but were very much anticipated by the respondents to help them recover after the flood disaster.

"I think most of the flood victims including me are really hoping for emotional support. If anyone can give us emotional support it would be great .. because we really need it in this situation"

(Respondent 11)

Emotional support was one of the most desired supports among the respondents that would help them rise and continue with their lives. Emotional support is defined as empathy and support towards the psychological problems that the respondents face, especially motivating the respondents' spirit in building new lives after the incident. According to Burleson and MacGeorge (2002), emotional support comprises expressions in communication to indicate concern and reassurance towards an individual to rise again after going through a tough situation. Emotional support is frequently related to better health and well-being. Besides, emotional support functions as a way to ease the anxiety and distress faced by an individual by promoting support acceptance (Priem \& Solomon, 2014).

Besides these three types of support, this study also discovered that the respondents hoped for informational support such as advice and useful information to assist them to solve their problems, especially related to permanent housing and economic recovery assistance, as mentioned by the thirteenth respondent.

" As a flood victims, I really need valid information especially anything related to permanent house assistance and economic recovery advice .. I think the government 
needs to consider how to distribute the right information and make sure that the information reaches us."

(Respondent 13)

Prior researches have shown that information support such as advice and guidance can assist individuals to overcome their problems (Gelbrich, 2010). Bailey et al. (2010) also mentioned that information support received by individuals could significantly decrease anxiety and psychological distress when handling problems. Therefore, some respondents have recommended that the government should consider the best method to provide and share information related to flood victims, as well as to ensure that this information reaches the targeted people successfully. If the specified information regarding housing provision or economic recovery advice is properly provided, the flood victims will be able to live better new lives after flooding events.

\section{Conclusion}

In conclusion, the resilience level of the respondents that participated in this study was influenced by four major factors, namely the flood victims' self-efficacy, coping strategies applied, the characteristics of community spirit existing in the settlement areas, and the social support provided to the flood victims. The findings prove that to enhance the resilience of flood victims, their inherent self-efficacy should be enhanced. Besides, the coping strategies that the flood victims applied need to be improved, and the positive spirit among the community members needs to be strengthened. Finally, apart from tangible support and social relationship support between family members and the community, emotional support and information support also need to be upgraded or enriched to suit the necessities of the flood victims to help them recover quickly after a disaster.

Hence, this study proposes all factors influencing flood resilience to be taken into consideration by related Malaysia agencies such as the National Disaster Management Agency (NADMA), the Department of Social Welfare, the District Offices, and the Post Flood Recovery Unit. These related units are required to formulate interventions to promote community involvement in improving self-defence, as well as family and community resilience when faced with disaster risks. Besides, the Sendai Framework (2015-2030) should be implemented to emphasise the role of society in managing and reducing disaster risks. This approach promotes community participation in disaster management, especially in lessening disaster risks. This in line with National Social Welfare Policy (2003), which states the importance of developing an individual's potential to the optimum level, as well as enhancing community resilience in facing current challenges is by building and nurturing an attitude of helping each other for the benefit and well-being of the community.

\section{Acknowledgements}

We would like to express our sincere gratitude to Faculty of Social Sciences and Humanities (FSSK) and Universiti Kebangsaan Malaysia (UKM).This article is a part of Universiti Kebangsaan Malaysia research grant scheme (Grant Code: GGPM- 2019- 040). The grant was funded by Universiti Kebangsaan Malaysia.

\section{References}

Bailey, J., Sabbagh, M., Loiselle, C. G., Boileau, J., \& McVey, L. (2010). Supporting families 
in the ICU: A descriptive correlational study of informational support, anxiety, and satisfaction with care. Intensive and Critical Care Nursing, 26, 114-122. doi:10.1016/j.iccn.2009.12.006

Berkman, L. F., Glass, T., Seeman, I., \& Brisette, T. E. (2000). From social integration to health: Durkheim in the new millennium. Social Science and Medicine, 51, 843-857. doi:10.1016/S0277-9536(00)00065-4

Bisschop, M. I., Knegsman, D. M. W., Beekman, A. T. F., \& Deeg, D. J. H. (2004). Chronic diseases and depression: The modifying role of psychosocial resources. Social Sciences and Medicine, 59, 721-733. doi:10.1016/j.socscimed.2003.11.038

Braun, V., \& Clarke, V. (2006). Using thematic analysis in psychology. Qualitative Research in Psychology, 3(2), 77-101. doi:10.1191/1478088706qp063oa

Brown, B. B., Perkins, D., \& Brown, G. (2003). Place attachment in a revitalizing neighbourhood: Individual and block levels of analysis. Journal of Environmental Psychology, 23, 259-71. doi:10.1016/S02724944(02)001172

Brown, S. P., Westbrook, R. A., \& Challagalla, G. (2005). Good cope, bad cope: Adaptive and maladaptive coping strategies following a critical negative work event. Journal of Applied Psychology, 90(4), 792-798. doi:10.1037/0021-9010.90.4.792

Burleson, B. R., \& MacGeorge, E. L. (2002). Supportive communication. In M. L. Knapp \& J. A. Daly (Eds.), Handbook of Interpersonal Communication. Thousand Oaks, CA: Sage.

Carver, C. S., Scheier, M. F., \& Weintraub, J. K. (1989). Assessing coping strategies: A theoretically based approach. Journal of Personality and Social Psychology, 56 (2), 267283. doi:10.1037/0022-3514.56.2.267

Chaplin, J. P. (2004). Dictionary of Psychology. Jakarta: Raja Grafindo Persada.

Department of Drainage and Irrigation Kelantan (2015). Paper presented at the 2015 Kelantan Flood Management Conference: Resolution, Framework and Sustainable Development. Kubang Kerian, Kelantan: University of Sciences Malaysia.

Economic Planning Unit of Kelantan State. (2015). Paper presented at the Flood Management Conference: Resolution, Framework and Sustainable Development. Kubang Kerian, Kelantan: University of Sciences Malaysia.

Faure, S., \& Loxton, H. (2003). Anxiety, depression and self-efficacy levels of women undergoing first trimester abortion. South African Journal of Psychology, 33, 28-38. doi:10.1177/008124630303300104

Gelbrich, K. (2010). Anger, frustration, and helplessness after service failure: Coping strategies and effective informational support. Journal of the Academy of Marketing Science, 38, 567-585. doi 10.1007/s11747-009-0169-6.

Faure, S., \& Loxton, H. (2003). Anxiety, depression and self-efficacy levels of women undergoing first trimester abortion. South African Journal of Psychology, 33, 28-38. doi:10.1177/008124630303300104

Karademas, E. C. (2006). Self-efficacy, social support and well-being. The mediating role of optimism. Personality and Individual Differences, 40, 1281-1290. doi:10.1016/j.paid.2005.10.019

Kashdan, T. B., \& Roberts, J. E. (2004). Social anxiety's impact on affect, curiosity, and social self-efficacy during a high self-focus social threat situation. Cognitive Therapy and Research, 28, 119-141. doi:10.1023/B:COTR.0000016934.20981.68

Kuijer, R. G., \& de Ridder, D. (2003). Discrepancy in illness-related goals and quality of life in chronically ill patients: The role of self-efficacy. Psychology and Health, 18, 313-330. doi:10.1080/0887044031000146815 
Malecki, C. K., \& Demaray, M. K. (2003). What type of support do they need? Investigating student adjustment as related to emotional, informational, appraisal, and instrumental support. School Psychology Quarterly, 18 (3), 231-252. doi:10.1521/scpq.18.3.231.22576.

Maruzairi, H., Zawari, M. N., \& Arifin, W. N. M. (2015). Exploring emotion disasters and resilience in adolescent affected by flood in Kelantan and the development of peer support group for trauma module. Final Report of the Flood Research Conference 2014 (pp. 244-247): University of Technology Malaysia.

Mendelson, M. B., Catano, V. M., \& Kelloway, K. (2000). The role of stress and social support in sick building syndrome. Work \& Stress, 14, 137-155. doi:10.1080/026783700750051658

Noremy, M. A., Saadah, N. M. A., \& Jana, N. S. (2019a). Floods and psychological problems: Managing stress during floods. In Jamiah M., Suzana, M. H. \& Hilwa, A. Stress Management. Selangor, Malaysia: UKM Publisher

Noremy, M. A., Rahim, M. K., Sofia, A., Helma, R. M., \& Hafizah, N. M. A. (2019b). Exploring the coping strategies that improve resiliency among flood victims in Kelantan, Malaysia. International Journal of Recent Technology and Engineering, 8(2S10), 67-73.

Norizan, Y. (2016). Management of psychological elements in disaster preparedness: A qualitative study of flood victims in Kelantan. Malaysian Journal of Psychology, 30 (2), 74-81.

Paton, D. (2005). Community resilience: Integrating hazard management and community Engagement. International Conference on Engaging Communities, 14 ${ }^{\text {th }}-17^{\text {th }}$ June 2005. Queensland, Australia.

Peeters, M. C. W., \& Le Blanc, P. M. (2001). Towards a match between job demands and sources of social support: A study among oncology care providers. European Journal of Work and Organizational Psychology, 10, 53-72. doi:10.1080/13594320042000034

Perkins, D. D., \& Long, D. A. (2002). Neighbourhood sense of community and social capital : A multi-level analysis. In A. Fisher, C. Sonn, \& B. Bishop (Eds.), Psychological Sense of Community: Research, Applications, and Implications. New York: Plenum.

Pfefferbaum, R. L. (2013). The communities advancing resilience toolkit (CART): An intervention to build community resilience disasters. Journal of Public Health Management Practice, 19(3), 250-258. doi:10.1097/PHH.0b013e318268aed8

Priem, J. S., \& Solomon, D. H. (2014). Emotional support and physiological stress recovery: The role of support matching, adequacy, and invisibility. Communication Monographs, 82 (1), 88-112. doi:10.1080/03637751.2014.971416

Rohani, N. (2015). Malaysian Prime Bulletin [Television Broadcast]. Petaling Jaya, Malaysia: Media Prima.

Rosnah, I., Ferlis, B., Jasmine, A. M., Shuhairimi, A., Kasturi, M. N. A., Adila, I., \& Siti Zaleha, I. (2015). Intervention guideline and model programme for strengthening family community resilience in traumatic loss and major disasters. Final Report of the Flood Research Conference 2014 (pp. 248-251): University of Technology Malaysia.

Sikh, G. (2015). Reflections from Flood Events in Kelantan. Kelantan Mental Health Conferences. Kelantan: Health Department of Kelantan State.

Siti Uzairiah, M. T. (2016). Qualitative Research, Interview Analysis \& Nvivo11 Exploration. Kuala Lumpur: Aras Publisher.

Symister, P., \& Friends, R. (2003). The influence of social support and problematic support on 
optimism and depression in chronic illness: A prospective study evaluating self-esteem as a mediator. Health Psychology, 22, 123-129.

Hassan, W.A, Subramaniam, S., \& Yap, K.S. (2012). Paper presentation at the Natural Disaster and Climate Change Seminar. Bangi, Selangor: National University of Malaysia.

Nik, W. Y. (2015). Kelantan Flooding on December 2014: A disaster. Retrieved September 18, 2019 from pks.kelantan.gov.my/?p=82

Zainuddin, A. (2012). Research Methodology and Data Analysis ( $2^{\text {nd }}$ ed.) Malaysia: UiTM Press. 